\title{
Isolation, purification and characterization of Phospholipase D from almond (Amygdalus spinosissima) from Ziarat, Balochistan
}

\author{
Mahgul Baloch ${ }^{1}$, Ashif Sajjad ${ }^{1 *}$, Sabeena Rizwan ${ }^{2}$, Shaista Anjum³, \\ Nukhba Akbar ${ }^{2}$, Irfan Hafeez ${ }^{4}$ and Khalid Mahmood ${ }^{1}$ \\ 1. Institute of Biochemistry, University of Balochistan, Sariab Road-87300, Quetta, Pakistan \\ 2. Department of Chemistry, Sardar Bahadur Khan, Women's University, Brewery Road, Quetta, Pakistan \\ 3. Department of Botany, University of Balochistan, Sariab Road-87300, Quetta, Pakistan \\ 4. PCSIR Laboratories Complex, Ferozepur Road, Lahore-54600, Pakistan \\ *Corresponding author's email: ashifsajjad@hotmail.com ; ashif.sajjad@um.uob.edu.pk \\ Citation \\ Mahgul Baloch, Ashif Sajjad, Sabeena Rizwan, Shaista Anjum, Nukhba Akbar, Irfan Hafeez and Khalid \\ Mahmood. Isolation, purification and characterization of Phospholipase D from almond (Amygdalus \\ spinosissima) from Ziarat, Balochistan. Pure and Applied Biology. Vol. 11, Issue 2, pp661-.669. \\ http://dx.doi.org/10.19045/bspab.2022.110067
}

\begin{tabular}{llll}
\hline \hline Received: 13/08/2021 & Revised: 19/09/2021 & Accepted: 22/09/2021 & Online First: 25/09/2021 \\
\hline
\end{tabular}

\section{Abstract}

This study was carried out for the isolation, purification, and characterization of enzyme phospholipase D (PLD) from Amygdalus spinosissima Bunge (wild thorny almond). It was observed that the crude extract showed higher values of enzyme activity $1206 \mathrm{U}$ than that of purified which was found to be $915 \mathrm{U}$. The optimum time for extraction was 1.5 hours, after which the activity started decreasing. Purification of enzyme was done by hydrophobic interaction chromatography with a specific effect of calcium using Octyl Sepharose. In the absence of calcium ion, the fraction eluted from the column showed high enzymatic activity. The highest specific activity $\left(4575 \mathrm{Umg}^{-1}\right)$, purification fold (53.2) and yield (75.8\%) were obtained. Molecular weight was estimated as $62 \mathrm{kDa}$ by SDS-PAGE (sodium dodecyl sulfatepolyacrylamide gel electrophoresis) analysis. Highest activity of PLD was observed at $50^{\circ} \mathrm{C}$ and at $6 \mathrm{pH}$. Calcium ion stability of PLD activity was found at $40-90 \mathrm{mM}$. It is concluded from the present study that PLD has numerous industrial applications. It can be extracted and purified from A. spinosissima which is a cheap and easily available source at industrial scale.

Keywords: Activity; Amygdalus spinosissima; Isolation; Phospholipase D; Purification

\section{Introduction}

Almond, wild thorny almond (A. spinosissima) is one of the most important genera in the family Rosaceae. Iran is considered as the core centre of its diversity, from the southern to northern slopes the species of this genus are found. In the neighbouring countries like Afghanistan, Pakistan, Tajikistan, Turkey, Turkmenistan and Uzbekistan different species of Amygdalus are also found [1]. In Pakistan A. spinosissima is found on the sloppy hill of cold and dry areas of Balochistan province, approximately at 600 to 1500 metre altitude [2].

Phospholipase D (PLD) is a universal enzyme that is broadly spread in prokaryotic and eukaryotic systems and performs several functions in cellular glycerol-phospholipids, membrane 
degradation and reorganization [3]. It was first found in plants, afterward discovered in animals, fungi and bacteria. A novel gene phospholipase $\mathrm{D}$ was identified from a new strain of bacteria, Bacillus cereus ZY12 in recent years. The expression of gene is affected by different sources of carbon in this strain [4]. Phospholipase D breaks phosphodiester bonds of glycerolphospholipids at the terminals and converts phosphoglycrides into phosphatidic acid and free hydrophilic head group [5]. Phospholipids are the initial and chief components of biological membranes that are cut by the enzymes, hydrolases (phospholipases). Phospholipases comprises essential and complex class of enzymes that catalyse the phospholipid hydrolyses at ester or phosphodiester bond. Phospholipases are classified into A1, A2, $\mathrm{B}, \mathrm{C}$ and $\mathrm{D}$ [3]. The hydrolysis of ester bond in $s n-1$ and $s n-2$ position is catalysed by phospholipase A1 and A2. Phospholipase B catalyses the hydrolysis of glycerolphospholipids. Phospholipase C (PLC) hydrolyses is responsible for phosphodiester bond at the glycerol side and phospholipase D (PLD) catalyses the hydrolysis at the polar side [6]. In the presence of suitable acceptor alcohol, it catalyses the hydrolysis of transesterification reaction. Different studies reported that phospholipase D has fast and dramatic response to extra cellular stimuli due to which it is an important "signal activated" phospholipase and become an area of interest for researchers in molecular biology. Phospholipase D exists in different forms having difference in their regulation but mostly catalyse the hydrolysis of phosphatidylcholine. PLD plays various regulatory roles in different processes of plants, including programmed cell death, abscisic acid signalling, root growth, root hair patterning, freezing tolerance and other stress response [7]. Phospholipase D has been involved in a various cellular processes including alternation in cell motility and morphology, intracellular protein trafficking and secretion. Recently it has been shown that phospholipase $\mathrm{D}$ plays a demanding role in neurodegenerative and traumatic disorders and central nervous system ischemia [8]. Membrane PLD has neuronal functions including axonal growth, formation of secretory vesicles, synaptogenesis, apoptosis and neurodegeneration [9]. Resent reports suggest that a common neurodegenerative disorder Alzheimer's disease can be inhibited by PLD and is also used in the treatment of cancer [10].

PLD plays a significant role in metabolism of animals and plants and has been identified from several sources. The current study is aimed at the enzyme PLD isolation, purification and its characterization from $A$. spinosissima Bunge (wild thorny almond) and to report the presence of this enzyme in this specie. This wild plant species is selected for its importance in flora of Balochistan and is explored, to ensure utilization of local resources while monitoring sustainable biodiversity conservation and to the best of authors knowledge related to this specie no work has been published.

\section{Materials and Methods Material}

Lecithin (phosphatidyl choline) from egg yolk, ammonium reineckate (ammonium tetrathiocyanodiammonochromate),

PIPES, choline chloride, Octyle Sepharose, and all other chemicals of American Chemical Society (ACS) reagent grade were used.

\section{Sample collection}

A. spinosissima samples were collected from Ziarat district of Balochistan province, Pakistan. The seeds were washed with distilled water and then dried. The sample was crushed with the help of pestle and mortar using liquid nitrogen and stored at $20^{\circ} \mathrm{C}$.

\section{Extraction}

PLD was extracted according to Tosi et al, [11]. The sample was weighted $5.0 \mathrm{~g}$ and mixed in $50 \mathrm{ml}$ of $0.1 \mathrm{M}$ sodium acetate buffer ( $\mathrm{pH}$ 5.6). The solution was then kept on shaker for 1.5 hours at $4^{\circ} \mathrm{C}$. The 
dissolved sample was transferred to centrifuge tubes and was centrifuge at $5000 x g$ for 10 minutes in a refrigerated centrifuge machine. The supernatant was transferred to an Erlenmeyer flask and then was divided into two equal parts, one part for activity determination and the second part for purification of PLD.

\section{Determination of PLD activity}

By following Tosi et al. [11], the activity of PLD was determined according to Bergmeyer \& Gavehn, [12]. Supernatant $(10 \mathrm{ml})$ was transferred in an Erlenmeyer flask. The percentage of egg yolk lecithin was $(0.5 \%)$ which was prepared in ethyl ether solution. Lecithin solution $(10 \mathrm{ml})$ and $0.1 \mathrm{M}$ calcium chloride $(0.1 \mathrm{ml})$ was added to the supernatant. The solution was dissolved by shaking at $5^{\circ} \mathrm{C}$ for 180 minutes with shaker machine. Trichloroacetic acid (3M) was added about $1.0 \mathrm{ml}$ to the solution to terminate the hydrolysis step. Ethyl ether was removed by using vacuum rotary evaporator. The solution was centrifuged for 10 minutes at $14000 \mathrm{xg}$. Supernatant $6 \mathrm{ml}$ was transferred to a conical centrifuge tube and $1.0 \mathrm{ml}$ of $3 \%$ ammonium reineckate (ammonium

tetrathiocyanodiammonochromate) in solution containing methanol was added and vortexed. Appearance of light violet, pink colour correspondent to choline reinekate was obtained. Then the obtained pink solution was centrifuged for 5 minutes at 5000xg. After discarding the supernatant, $3 \mathrm{ml}$ of distilled water was added and vortexed until the precipitates were suspended and then the solution was centrifuged at 5000xg for 10 minutes. The washing step was repeated again. After washing step, the supernatant was discarded and $3.0 \mathrm{ml}$ of acetone was added and vortexed till the precipitates were dissolved. Mixture was centrifuge $\mathrm{d}$ at $5000 x g$ for 5 minutes. Absorbance of the supernatant was measured against acetone blank at $520 \mathrm{~nm}$.

\section{Standard choline curve}

All procedures were repeated as in the method of extraction but choline standard solution was used in a specific amount (0.1432 m.moles of choline per $\mathrm{ml}$ of solution) instead of enzyme (sample). Trichloroacetic acid was used in the standard solution to stop the reaction. By using the given expression, the activity of PLD was estimated. During the experiment, one unit of enzyme (PLD) activity was defined as the amount of enzyme which releases $1 \mu$ mole of choline $\mathrm{min}^{-1}$. The choline quantification was determined by the corresponding measured absorbance value by using a standard choline curve with the correlation coefficient $\mathrm{R}^{2}=0.9904$.

\section{Purification of PLD}

The part of the supernatant of extraction which was stored for purification process was mixed with equal amount of chilled acetone for precipitation of protein. To recover the protein, the precipitated protein was centrifuged for 20 minutes at $18000 \mathrm{xg}$ and then in acetate buffer $0.1 \mathrm{M}, \mathrm{pH} 5.6$ was used to dissolve the precipitates.

The precipitated protein was purified according to Lambretch et al. [13] by Hydrophobic Affinity Chromatography with modifications to some extent. A minicolumn by using a Pasteur pipette with length of $59 \mathrm{~mm}$ and width of $15 \mathrm{~mm}$ was prepared and filled with $5 \mathrm{ml}$ of OctyleSepharose. The column was washed with buffer A $(50 \mathrm{mM} \mathrm{CaCl} 2,30 \mathrm{mM}$ PIPES $\mathrm{pH}$ 6.2). After washing, $5 \mathrm{ml}$ of crude plant extract was loaded on the column. Various fractions were collected by passing, buffer A $5 \mathrm{ml}$ for 6 times. While, buffer B $(30 \mathrm{mM}$ $\mathrm{CaCl}_{2}, 10 \mathrm{mM}$ PIPES pH 6.2) was passed 5 times and 6 times buffer $\mathrm{C}$ (0.1M EDTA, $10 \mathrm{mM}$ PIPES pH 6.2) was passed. Eighteen fractions were collected, and absorbance of each fraction was checked at $280 \mathrm{~nm}$. By elusion profile, the activity of phospholipase D was calculated in active fraction. The protein quantification in crude extract and active fraction was obtained by Bradford et al. [14] method.

\section{Characterization of phospholipase D}

The molecular weight of phospholipase D was determined by the process of SDSPAGE. Proteins were separated by using 10 
and/or $12.5 \%$ polyacrylamide resolving gel one dimensional SDS-PAGE with a discontinuous buffer system [15]. Wide range protein molecular weight marker ranging from (10 to $180 \mathrm{kDa}$ ) was used to determine the size of proteins. Gels were stained using Coomessie Brilliant Blue and/or silver staining by following the method of Heukeshoven \& Dernick, [16].

\section{Kinetic properties of extracted phospholipase D}

Various factors that affect the activity of Phospholipase D were determined by following the procedures by Sirkhada et al. [17] and Khatoon et al. [18] with slight modifications where needed.

\section{Effect of extraction time}

The extraction time determination and its effect on PLD activity, extraction was performed on different time intervals with the difference of half hour $(0.5,1,1.5,2$, 2.5, 3, 3.5 and 4 hrs).

\section{Effect of temperature}

The temperature effect on PLD activity, the reaction mixture was incubated at a range of different temperatures $\left(0-80^{\circ} \mathrm{C}\right)$ for 30 minutes (at each temperature) and for standard assay the sample ice bath was used to cooling purpose.

\section{Effect of pH}

To find out ideal $\mathrm{pH}$ for maximum PLD activity, different $\mathrm{pH}$ buffers were added (ranged from 4-10). The enzyme extraction was checked by using 4-5 sodium acetate buffer, PIPES buffer ranged from 6 to 7 and glycine- $\mathrm{NaOH}$ ranged from 8 to 10 .

\section{Effect of calcium ion}

Phospholipase $\mathrm{D}$ belong to the plants are considered $\mathrm{Ca}^{+2}$ dependent therefore, different calcium chloride concentration ranged from $(10 \mathrm{mM}$ to $120 \mathrm{mM})$, the enzyme solution was treated in order to evaluate the maximum enzyme activity.

\section{Results and discussion}

The present study was conducted for the purpose of isolation, purification and characterization of phospholipase D from a new source A. spinosissima almond. As almonds are nutritive and are high source of lipids containing lipase and phospholipase.
Due to its applications, phospholipase D was selected.

Phospholipase $\mathrm{D}$ was extracted by a method in which acetate buffer (0.1M pH 5.6) was used. Sample was dissolved in $5 \mathrm{~g}$ of buffer and homogenized by keeping the solution at a shaker machine for 90 minutes. Centrifugation was done at 5000xg for 10 minutes. Activity was determined by following Bregmayer \& Gavihn, [12] method. By using standard choline solution, a standard curve was obtained. The observed activity was found to be $1206 \mathrm{U}$ in crude sample and $915 \mathrm{U}$ in purified sample. It is shown by the result that crude extract has high activity then that of purified.

At various time intervals with difference of 30 min (30 mins to 4 hours), extraction was done in order to check the effect of time on PLD activity. The (Fig. 1) shows that 1.5 hrs is the best time for high enzyme activity the obtained result is similar with that of a previously published study on soybean [11] and was not in agreement with the results of a published study on Streptomyces recemochromogenes which was $1 \mathrm{hr}$ [19].

Hydrophobic affinity chromatography was used to purify PLD. A suitable binding material, Octyle sepaharose was used in the column. By using calcium chloride and PIPES, the elusion was done. The results obtained are shown in the (Fig. 2) which shows that the enzyme binds strongly with Octyl residue at high $\mathrm{Ca}^{+2}$ concentration (50 $\mathrm{mM}$ ) in buffer $\mathrm{A}$, because in this fraction no activity was noticed. The high peak at this portion was observed which shows that the majority of proteins are present in the crude. The proteins eluted because they didn't have any interaction with the medium. The proteins which were bounded loosely with the medium also eluted at low $\mathrm{Ca}^{+2}$ concentration in buffer $\mathrm{B}$ (i.e., 30 $\mathrm{mM})$. EDTA instead of $\mathrm{Ca}^{+2}$ was used in buffer $\mathrm{C}$, as a result PLD was eluted and showed a single peak which confirmed the activity in this fraction.

Quantity of protein was measured by Bradford quantification assay and at 595 
nm. After purification step, the specific activity and recovery rates of PLD are shown in the (Table 1). The protein concentration in crude was found to be 14 $\mathrm{mg}$ and in purified sample was $0.2 \mathrm{mg}$. A 53.2 purification fold was obtained with recovery of $75.8 \%$. From $5 \mathrm{~g}$ of sample about $0.2 \mathrm{mg}$ of purified PLD was obtained with specific activity of $4575\left(\mathrm{U} \mathrm{mg}^{-1}\right)$ which are not exactly same but near to the previously published on PLD from Streptomyces sanglieri [20] and from Indian mustard seed [18].

SDS-PAGE was done for molecular mass determination. Among different gel concentration, $10 \%$ acrylamide gel presents clear bands. Lane 1 shows the single band of purified sample, Lane 2 shows the bands of molecular mass marker ranges from 10$180 \mathrm{kDa}$ and Lane 3 represents the bands of crude sample as shown in (Fig. 3). Purified enzyme gave a single band with molecular mass calculated as $62 \mathrm{kDa}$ which showed close similarity to the molecular mass of PLD from Dacus carota which was $60 \mathrm{kDa}$ [19] and was $68 \mathrm{kDa}$ in Allium sativum bulbs and Brasslca Juncea seeds [7].

Effect of different factors (Temperature, $\mathrm{pH}$, calcium ion) was shown by its kinetic study (Table 2). PLD activity at different temperature $\left(10-80^{\circ} \mathrm{C}\right)$ was observed. $50^{\circ} \mathrm{C}$ was found optimum temperature for PLD activity as shown in (Fig. 4). The activity of PLD decreased gradually when the temperature was increased from $50^{\circ} \mathrm{C}$ to $80^{\circ} \mathrm{C}$. The enzyme does not lose its activity below $30^{\circ} \mathrm{C}$ and above $80^{\circ} \mathrm{C}$ which indicates that the enzyme is cold stable and thermostable. Same results were observed in publications by Liu et al. [22] from Jatropha curcas and by Khatoon et al. [16] from Indian mustard seed.

PLD activity was checked by treating it with various $\mathrm{pH}$ from 4-10 (4-5 sodium acetate buffer, PIPES buffer ranged from 6 to 7 and Glycine- $\mathrm{NaOH}$ ranged from 8 to 10) and $6 \mathrm{pH}$ was found ideal (Fig. 5). Enzyme also showed activity to some extent when the $\mathrm{pH}$ was increased to 9. The results agree as that of with previously recorded with Papaver somniferum L. PLD [23], Jatropha curcas [22] and Indian mustard seed [16].

Enzyme was treated with different calcium ion concentration $10-120 \mathrm{mM}$, among which $40 \mathrm{mM}$ was found best concentration of calcium ion for PLD activity. Enzyme showed notable activity from 50 to $90 \mathrm{mM}$ (Fig. 6). The obtained results of the study were found to be almost the same as were recorded in effect of calcium ion on sunflower [24] and in plant PLD [25].

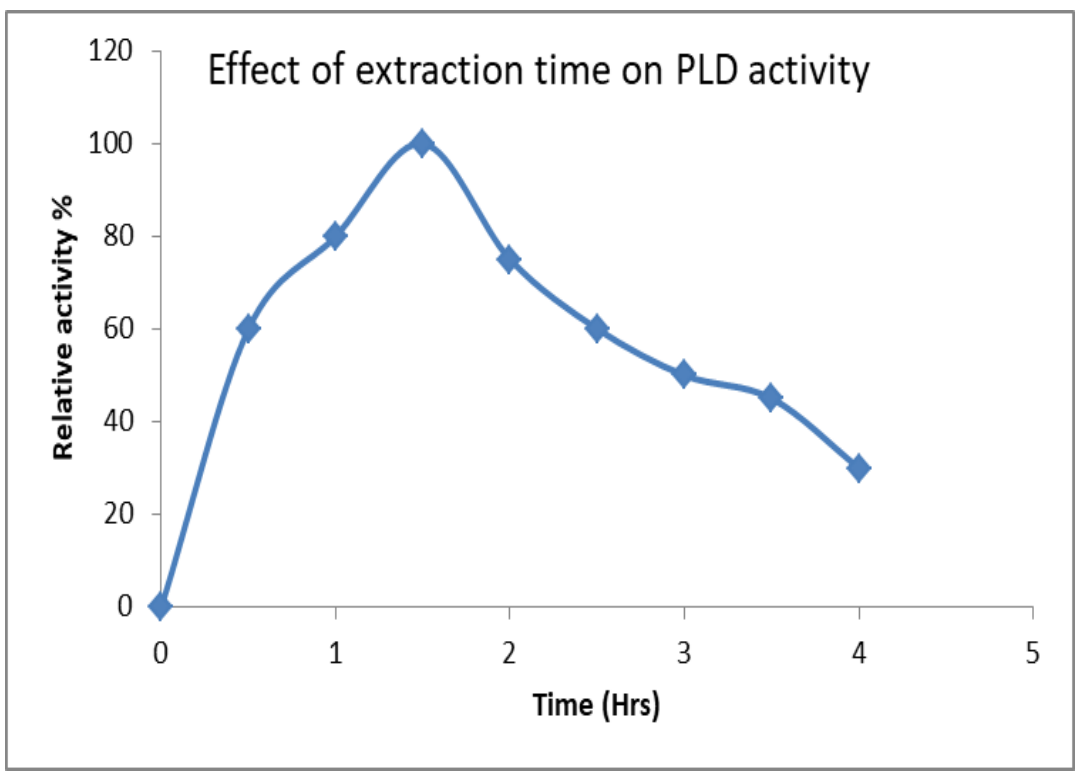

Figure 1. Effect of extraction time 


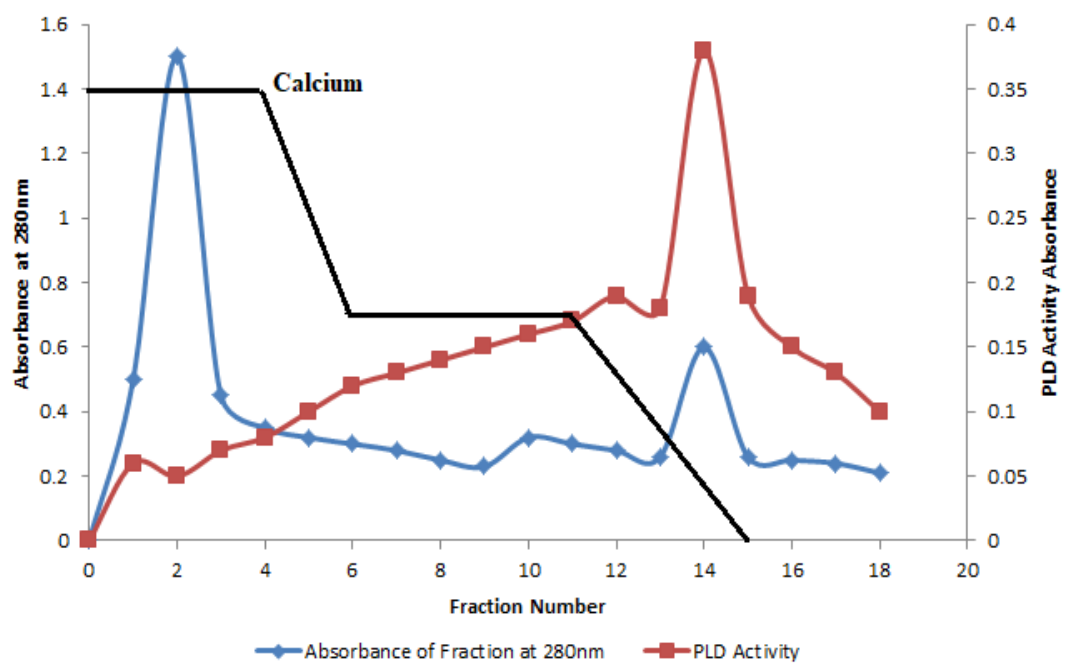

Figure 2. Elution profile of PLD on Octyle-Sepharose column

Table 1. PLD purification from A. spinosissima

\begin{tabular}{|c|c|c|c|c|c|c|}
\hline $\begin{array}{c}\text { S. } \\
\text { No. }\end{array}$ & $\begin{array}{c}\text { Purification } \\
\text { steps }\end{array}$ & $\begin{array}{c}\text { Protein } \\
(\mathbf{m g})\end{array}$ & $\begin{array}{c}\text { Activity } \\
(\mathbf{U})\end{array}$ & $\begin{array}{c}\text { Specific } \\
\text { Activity }_{\left(\mathbf{U m g}^{-1}\right)}\end{array}$ & Purification fold & $\begin{array}{c}\text { \%age } \\
\text { Yield }\end{array}$ \\
\hline 1 & Crude extract & 14 & 1206 & 86 & 1 & $100 \%$ \\
\hline 2 & Purified sample & 0.2 & 915 & 4575 & 53.2 & $75.8 \%$ \\
\hline
\end{tabular}

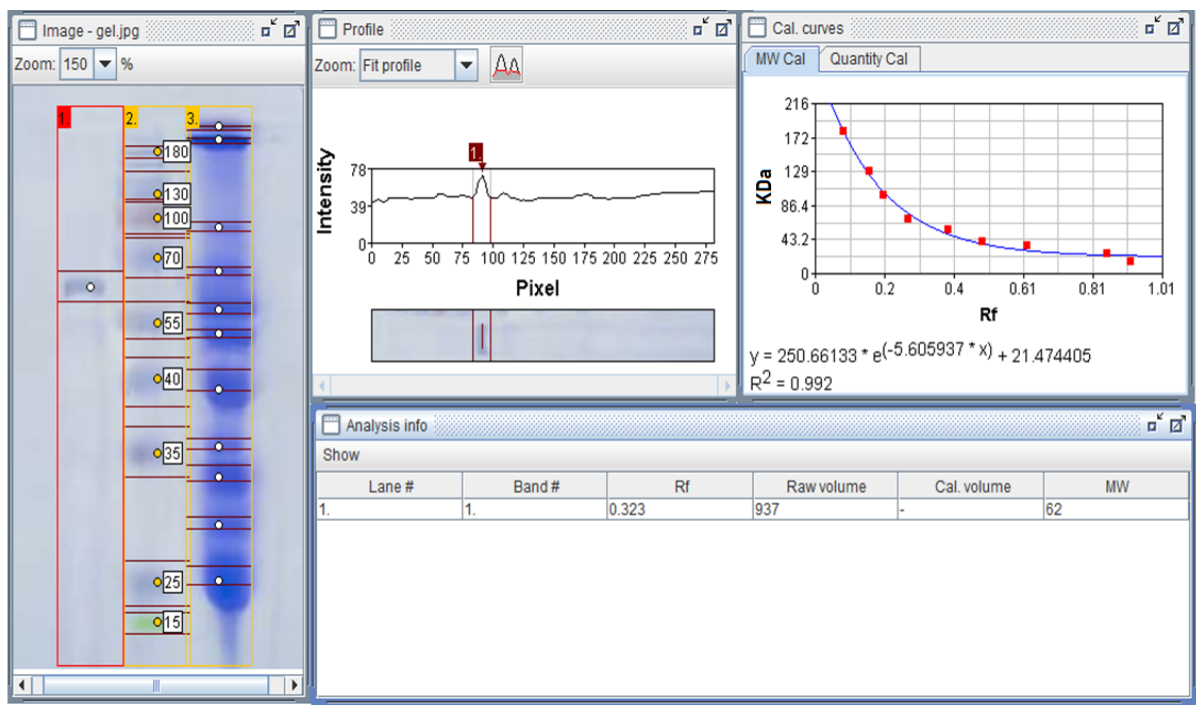

Figure 3. SDS- PAGE of Amygdalus spinosissima, Lane 1 represents the purified enzyme, Lane 2 protein Molecular weights markers and Lane 3 represents the crude fraction the gel visualized by coomassie blue staining. Rf analysis and molecular weight of Lanes by GelAnalyzer 2010a $@$

Table 2. Kinetic properties of $A$. spinosissima

\begin{tabular}{|c|c|c|c|c|c|c|c|}
\hline $\begin{array}{c}\text { Source of } \\
\text { PLD }\end{array}$ & $\begin{array}{c}\text { Specific } \\
\text { activity } \\
\text { (U/mg) }\end{array}$ & $\begin{array}{c}\text { Mol } \\
\text { Mass } \\
\text { kDa }\end{array}$ & $\begin{array}{c}\text { Optimum } \\
\mathbf{p H}\end{array}$ & $\begin{array}{c}\mathbf{p H} \\
\text { Stability }\end{array}$ & $\begin{array}{c}\text { Optimum } \\
\mathbf{T e m p} \\
\left.{ }^{\circ} \mathbf{C}\right)\end{array}$ & $\begin{array}{c}\text { Thermal } \\
\text { stability } \\
\left({ }^{\circ} \mathbf{C}\right)\end{array}$ & $\begin{array}{c}\mathbf{C a + 2} \\
\text { stability } \\
\mathbf{m M}\end{array}$ \\
\hline $\begin{array}{c}\text { Amygdallus } \\
\text { spinosissima } \\
\text { (Almond) }\end{array}$ & 915 & 62 & 6 & $4-9$ & 50 & $<30$ & $40-90$ \\
\hline
\end{tabular}




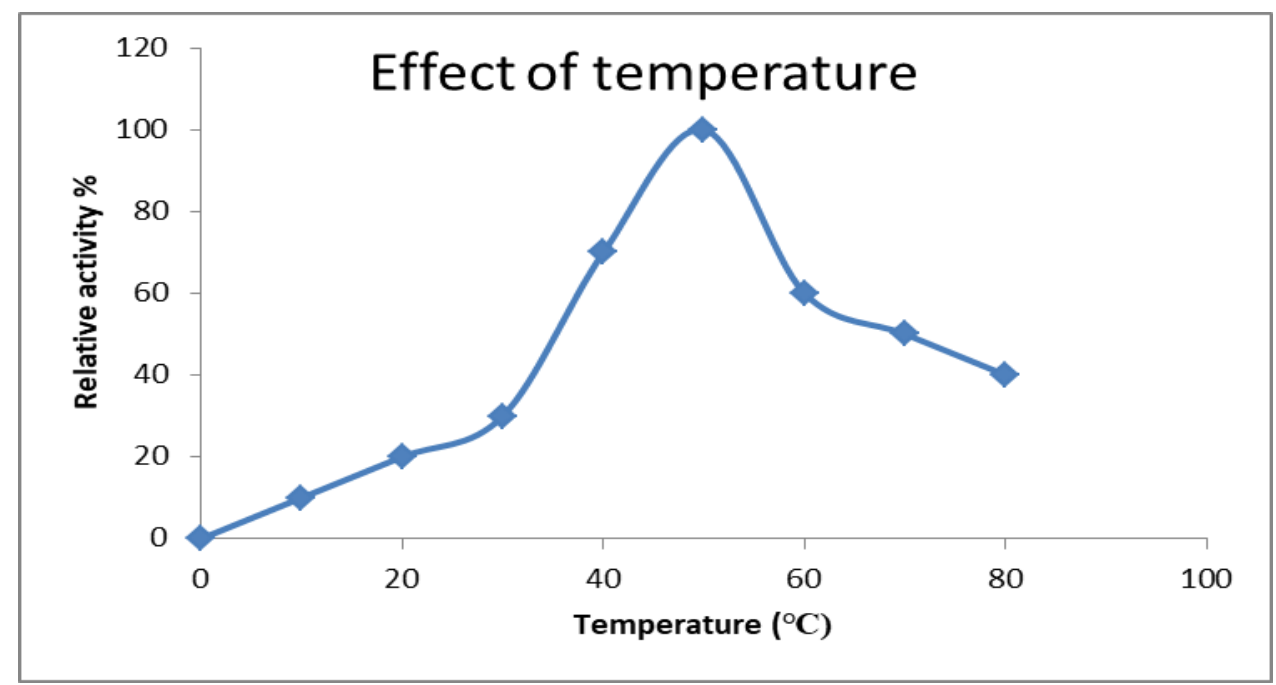

Figure 4. Temp effect on PLD activity of Amygdalus spinosissima

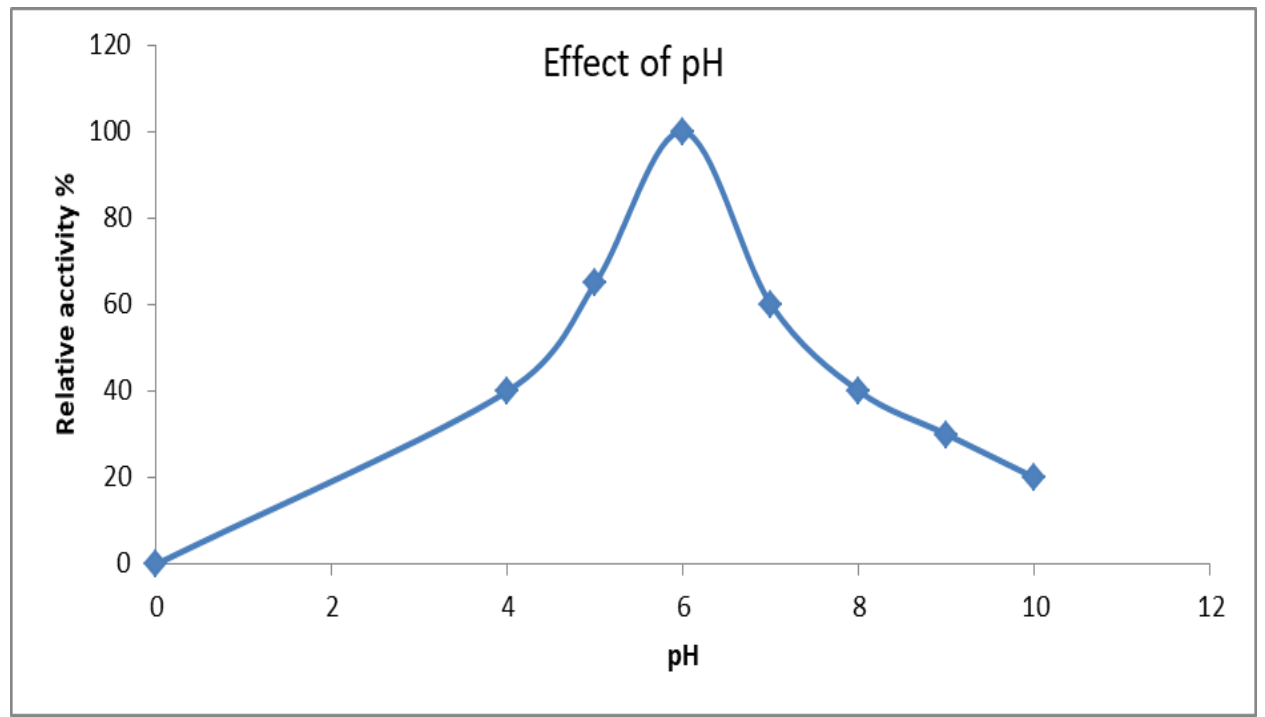

Figure 5. pH effect on PLD activity of Amygdalus spinosissima

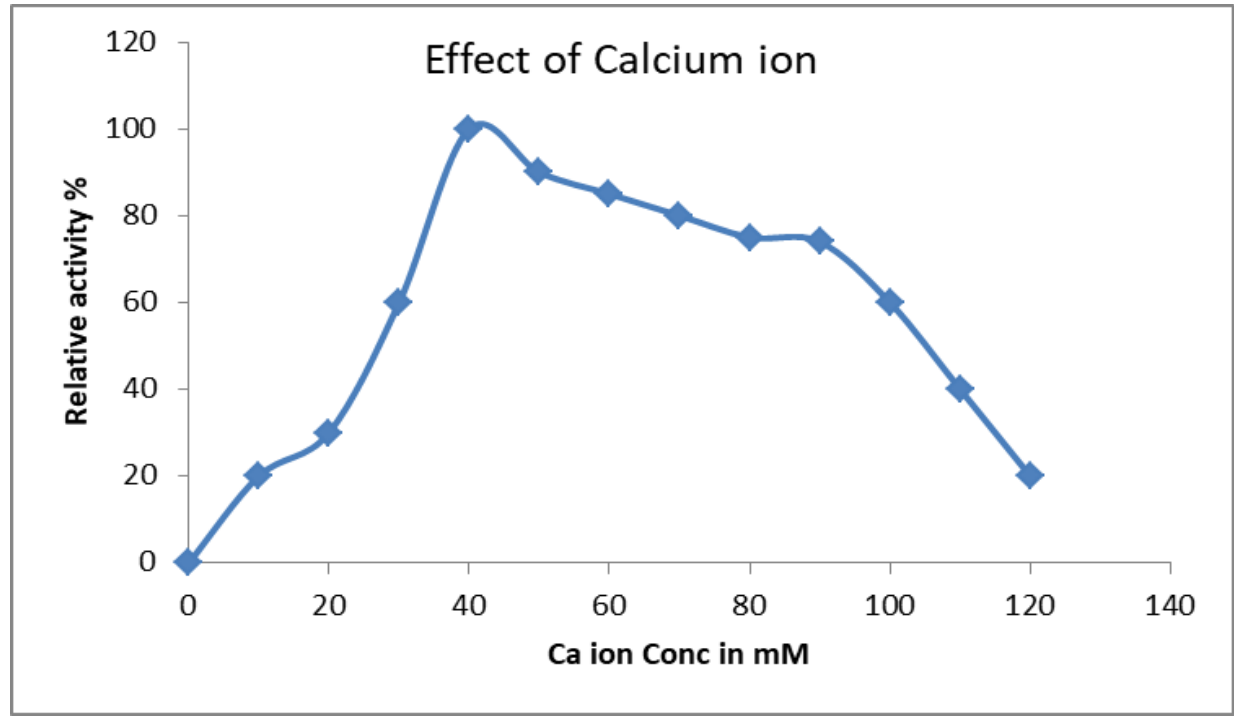

Figure 6. Calcium ion effect on PLD activity of Amygdalus spinosissima 


\section{Conclusion}

PLD has been purified successfully from crude extract of $A$. spinosissima with a specific activity of $4575 \mathrm{U} \cdot \mathrm{mg}^{-1}$ and yield of $75.8 \%$. The purification procedure included hydrophobic interaction chromatography by which 53.2 folds of purification was achieved. The molecular weight of $A$. spinosissima PLD was estimated $62 \mathrm{kDa}$ by SDS-PAGE. Enzyme activity was observed in various temperature ranges from 10 to $80^{\circ} \mathrm{C}$ among which $50^{\circ} \mathrm{C}$ was calculated optimum for PLD activity of $A$. spinosissima. $\mathrm{pH}$ for PLD activity in A. spinosissima was found acidic 6 among 4-10 pH range. Remarkable activity was shown in $40 \mathrm{mM}$ of calcium ion when the enzyme was treated with different calcium chloride concentration ranged from $10-120 \mathrm{mM}$. It is concluded that $A$. spinosissima may be considered a new economical source for PLD and can be isolated at industrial scale.

\section{Authors' contributions}

Conceived and designed the experiments: $M$ Baloch, A Sajjad \& S Rizwan, Performed the experiments: M Baloch, S Rizwan, S Anjum \& N Akbar, Analyzed the data: A Sajjad, S Rizwan \& S Anjum, Contributed reagents/materials/ analysis: $\mathrm{K}$ Mahmood \& I Hafeez, Wrote the paper: M Baloch \& A Sajjad.

\section{Acknowledgement}

This work was supported by research grant No. UoB/ORIC/17/UBRF-17/004 under University of Balochistan Research Fund (UBRF). Thanks, to all those who helped us in the sample collection and preparation of this manuscript.

\section{References}

1. Browicz K \& Zohary D (1996). The genus Amygdalus L. (Rosaceae): specie relationships, distribution and evolution under domestication. Genet Resour Crop Evol 43(3): 229-247.

2. Dzhangaliev AD (2003). The wild apple tree of Kazakhstan. Horticultural Reviews-Westort Then New York 29: 63-304.
3. Khatoon H (2013). Phospholiase D from Indian Mustards Seeds: Purification and Enzymatic Characterization. PhD diss., Universitäts-und Landesbibliothek Sachsen-Anhalt.

4. Zhao Y, Xu Y, Yu F \& Zhang C (2018). Identification of a novel phospholipase $D$ gene and effects of carbon sources on its expression in Bacillus cereus ZY12. J Microbiol 56(4): 264-271.

5. Wang X (2000). Multiple forms of phospholipase D in plants: the gene family, catalytic and regulatory properties, and cellular functions. Prog Lipid Res 39(2): 109-149.

6. OisHi H, Morimoto T, Watanabe Y \& Tamai Y (1999). Purification and characterization of phospholipase B from Kluyveromyces lactis, and cloning of phospholipase B gene. Biosci Biotechnol Biochem 63(1): 83-90.

7. Liscovitch M, Czarny M, Fiucci G \& Tang X (2000). Phospholipase D: molecular and cell biology of a novel gene family. Biochem J 345(Pt 3): 401.

8. Khatoon H (2006). Identification, Characterization and Purification of Phospholipase D from Allium sativum Bulbs and Brassica juncea Seeds. PHD diss., Aligarh Muslim Uni, India

9. Krzystanek M, Krzystanek E, Skałacka K \& Pałasz A (2020). Enhancement in Phospholipase D Activity as a New Proposed Molecular Mechanism of Haloperidol-Induced Neurotoxicity. Int J Mol Sci 21(23): 9265.

10. Oliveira TG \& Di Paolo G (2010). Phospholipase D in brain function and Alzheimer's disease. Biochim Biophys Acta Mol Cell Biol Lipids 1801(8): 799805.

11. Tosi E, Ballerini G \& Ré E (2007). Soybean phospholipase D activity determination. A comparison of two methods. Grasas Y Aceites 58(3): 270274.

12. Bergmeyer HU, Gavehn K (1974). Method of enzymatic analysis. 2nd Ed., Academic Press., New York, 415-418. 
13. Lambrecht $\mathrm{R}$ \& Ulbrich-Hofmann $\mathrm{R}$ (1992). A facile purification procedure of phospholipase D from cabbage and its characterization. Biol Chem HoppeSeyler 373(1): 81-88.

14. Bradford MM (1976). A rapid and sensitive method for the quantification of microgram quantities of protein utilizing the principle of protein-dye binding. Anal Bioche Orlando, V 72.

15. Laemmli UK (1970). Cleavage of structural proteins during the assembly of the head of bacteriophage T4. Nature 227(5259): 680-685.

16. Heukeshoven J \& Dernick R (1985). Simplified method for silver staining of proteins in polyacrylamide gels and the mechanism of silver staining. Electrophoresis 6: 103-112.

17. Simkhada JR, Cho SS, Lee HJ \& Yoo JC (2007). Purification and biochemical properties of phospholipase d (PLD57) produced by Streptomyces sp. CS-57. Arch Pharm Res 30(10): 1302.

18. Khatoon H, Mansfeld J, Schierhorn A \& Ulbrich-Hofmann R (2015). Purification, sequencing and characterization of phospholipase D from Indian mustard seeds. Phytochem 117: 65-75.

19. Nakazawa Y, Sagane Y, Kikuchi T, Uchino M, Nagai T, Sato H \& Takano K (2010). Purification, biochemical characterization, and cloning of phospholipase D from Streptomyces racemochromogenes strain 10-3. The Protein J 29(8): 598-608.

20. Sugimori D, Ogasawara J, Okuda K \& Murayama K (2014). Purification, characterization, molecular cloning, and extracellular production of a novel bacterial glycerophosphocholine cholinephosphodiesterase from Streptomyces sanglieri. J Biosci Bioeng 117(4): 422-430.

21. Sharma S \& Gupta MN (2001). Purification of phospholipase D from Dacus carota by three-phase partitioning and its characterization. Protein Expr Purif 21(2): 310-316.

22. Liu B, Yao L, Wang W, Gao J, Chen F, Wang S \& Jia Y (2010). Molecular cloning and characterization of phospholipase D from Jatropha curcas. Mol Biol Rep 37(2): 939.

23. Lerchner A, Mansfeld J, Schäffner I, Schöps R, Beer HK \& UlbrichHofmann R (2005). Two highly homologous phospholipase D isoenzymes from Papaver somniferum L. with different transphosphatidylation potential. Biochim Biophys Acta Mol Cell Biol Lipids 1737(2-3): 94-101.

24. Abdelkafi S \& Abousalham A (2011). Kinetic study of sunflower phospholipase Da: interactions with micellar substrate, detergents and metals. Plant Physiol Biochem 49(7): 752-757.

25. Dreßler L, Michel F, Thondorf I, Mansfeld J, Golbik R \& UlbrichHofmann R (2017). Metal ions and phosphatidylinositol 4, 5-bisphosphate as interacting effectors of $\alpha$-type plant phospholipase D. Phytochem 138: 5764. 